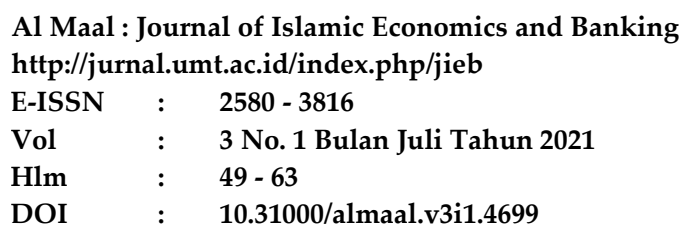

\title{
Virtual Property Pada Game Online Dalam Perspektif Hukum Ekonomi Syariah
}

\author{
Misno ${ }^{1 *}$ \\ ${ }^{1}$ Prodi Ekonomi Syariah, Pascasarjana Institut Agama Islam Sahid Bogor, Indonesia \\ *drmisnomei@gmail.com
}

\begin{abstract}
The development of technology has brought a variety of high-tech entertainment, one of which is developing games both offline and online. Online games are games that are widely enjoyed, especially by children and teenagers. Today's online game play is not just a game, but in it there are economic activities in the form of buying and selling which have an effect on ownership of virtual objects. The conclusion of this study is that Virtual Property can be recognized as a treasure in Islam. Although it does not have a real form, there is a value that is recognized by the community so that it becomes part of the property. Because it is recognized as property, buying and selling with this object is permissible and lawful. Recognition of the existence of virtual property is based on the theory of urf, namely that everything that is considered good and permissible by the community can then be a legal argument.
\end{abstract}

Keywords: Application; Ar-Rahn; Islamic law; Mulia products.

\begin{abstract}
ABSTRAK
Perkembangan tekhnologi telah menghadirkan berbagai hiburan bertekhnologi tinggi, salah satu yang berkembang adalah game (permainan) baik yang bersifat offline ataupun online. Game online menjadi permainan yang banyak dinikmati khususnya oleh anak-anak dan remaja. Permainan game online saat ini bukanlah hanya sebatas permainan, namun di dalamnya terdapat aktifitas ekonomi dalam bentuk jual beli yang berefek pada kepemilikan atas bendabenda yang bersifat virtual (Virtual Property). Kesimpulan dari penelitian ini adalah bahwa Virtual Property bisa diakui sebagai harta dalam Islam. Walaupun tidak memiliki bentuk riil namun adanya value (nilai) yang diakui oleh masyarakat sehingga menjadi bagian dari harta. Karena ia diakui sebagai harta maka jual beli dengan obyek ini diperbolehkan dan halal. Pengakuan terhadap keberadaan dari virtual property ini didasarkan pada teori urf, yaitu bahwasanya segala sesuatu yang dianggap baik da boleh oleh masyarakat maka itu bisa menjadi dalil hukum.
\end{abstract}

Kata kunci : Virtual Properties; Online game; 'Urf; Sharia Economic Law 


\section{Pendahuluan}

Perkembangan tekhnologi telah menghadirkan berbagai hiburan bertekhnologi tinggi, salah satu yang berkembang adalah game (permainan) baik yang bersifat offline ataupun online. Game online menjadi permainan yang banyak dinikmati khususnya oleh anak-anak dan remaja. Permainan game online saat ini bukanlah hanya sebatas permainan, namun di dalamnya terdapat aktifitas ekonomi dalam bentuk jual beli bendabenda yang bersifat virtual (Virtual Property) (Nasuzu, 2016).

Transaksi jual beli yang dilakukan di dalam game online diantaranya adalah dengan bertemu antara pemain (player) satu dengan lainnya, apabila player tidak satu daerah maka transaksi bisa melalui rekening bank ataupun dapat melalui website yang khusus untuk jual beli di dalam game online. Barang yang diperjualbelikan di dalam game online diantaranya, Id dan password game yang bersangkutan, mata uang di dalam game online contohnya di dalam game Ragnarok atau Rising Force (RF) harga mata uang game tersebut 1 juta uang game sama dengan Rp.2000-2500, barang-barang didalam game online diantaranya senjata (weapon), baju (armor), cincin (ring elemental) dan lain sebagainya.

Saat ini gameonline merupakan permainan yang sangat digemari tidak hanya oleh anak-anak bahkan remaja, dewasa, juga orang tua juga menyukainya. Terlebih berbagai macam game telah banyak berubah, ada yang berbentuk science yang berisi tentang pendidikan, atau game adventure yang membuat pemain dapat mengeksplor sebuah dunia yang ada didalam game dan bermacam game lain yang sesuai dengan berbagai usia.

Penghasilan yang didapat dari bermain game online juga tidak sedikit bahkan dapat mengalahkan penghasilan yang ada dalam bekerja secara nyata, dalam prosesnya penghasilan yang didapatkan melalui game adalah dengan cara seorang pemain menjual item atau barang-barang kepada pemain yang didapatkan dari hasil menyelesaikan suatu misi dalam game atau juga dapat dihasilkan dengan cara menjual ID karakter yang dimiliki seorang pemain kepada pemain yang lain.

Islam memandang bahwa harta sejatinya adaah segala sesuatu yang memiliki nilai di masyarakat. Pada masa lalu harta adalah kambing, emas dan perak serta uang dan harta benda yang bersifat materiil dan berwujud. Namun dengan berkembangnya zaman maka harta tidak lagi dalam bentuknya yang riil, banyak hal yang tidak nampak dan tidak terlihat bentuknya namun juga bisa dikatakan sebagai harta. Sebagai contoh Hak Atas Kekayaan Intelektual atau HAKI, misalnya Hak Cipta. Pada hakikatnya hak cipta tidaklah berwujud, namun karena ia memiliki nilai maka dapat diterima sebagai harta dalam Islam. Sehingga jual beli atas hak cipta diperbolehkan (Prawiro, 2014).

Pada game online berbagai hal yang mendukung permainan tersebut dianggap sebagai harta dan dijualbelikan dengan menggunakan uang riil. Padahal benda-benda tersebut hakikatnya hanyalah hanya virtual bukan merupakan benda berwujud, namun para pemain game online mengakuinya sebagai kepemilikan dan mereka melakukan jual beli atas kepemilikan virtual tersebut.

Pertanyaan yang muncul adalah Bagaimana hukum ekonomi syariah mengenai Virtual Property? Apakah ia merupakan bagian dari harta yang diakui dalam Islam? 
Bagaimana hukum jual beli dengan obyek ini? artikel ini akan membahas dan menjawab pertanyaan ini dengan menggunakan pendekatan Hukum Ekonomi Syariah.

\section{KAJIAN LITERATUR Harta dalam Perspektif Hukum Ekonomi Syariah}

Harta dalam bahasa Arab disebut المال (al-mal) dan bentuk plural atau jama'nya adalah الأموال(al-amwal) menurut etimologi kata al-mal berarti condong, miring dan juga berpaling (Hasan, 2004), seperti disebutkan dalam Al-Qur'an :

$$
\text { والله يريد أن يتوب عليكم ويريد الذين يتبعون الشهوات أن تميلوا ميلا عظيما }
$$

Dan Allah hendak menerima taubatmu, sedang orang-orang yang mengikuti hawa nafsunya bermaksud supaya kamu berpaling sejauh-jauhnya (dari kebenara ). QS AnNisaa ayat 27 .

$$
\text { كان غفورا رحيما تستطوا أن تعدلوا بين النساء ولو حرصتم فلا تميلوا كل الميل فتذروها كالمعلقة وإن تصلحوا وتتقوا فإن الله }
$$

Dan kamu sekali-kali tidak akan dapat berlaku adil di antara isteri- isteri (mu), walaupun kamu sangat ingin berbuat demikian, karena itu janganlah kamu terlalu cenderung (kepada yang kamu cintai), sehingga kamu biarkan yang lain terkatungkatung. Dan jika kamu mengadakan perbaikan dan memelihara diri (dari kecurangan), maka sesungguhnya Allah Maha Pengampun lagi Maha Penyayang. QS An-Nisaa ayat 129.

Merujuk pada dua ayat ini maka makna maala-yamiilu-mailan adalah condong dan miring pada salah satu bagian.

Sedangkan harta menurut terminology yaitu :

$$
\text { ما يميل عليه طبع الإنسات ويمكن 'دخاره الى وقت الحاجة ـ أو كان ما يمكن حيازته و'حرازه ويتنفع كزز }
$$

Segala yang diminati manusia dan dapat dihadirkan ketika diperlukan atau segala sesuatu yang dapat dimiliki, disimpan dan dapat dimanfaatkan (Haroen, 2000).

Definisi ini dikemukakan oleh ulama Hanafiya, dalam definisi ini tersirat bahwa manfaat tidak termasuk harta, karena manfaat termasuk milik. Adapun definisi selanjutnya diberikan oleh Jumhur Ulama :

$$
\text { كل ما له قيمة يلزم متلفها بضمانه }
$$

Segala sesuatu yang mempunyai nilai dan dapat dikenakanganti rugi bagi orang yang merusak atau melenyapkannya (Syafei, 2004).

$$
\text { المال هو كل عين ذات قيمة مادية بين الناس }
$$

Harta adalah segala sesuatu yang mempunyai nilai materi di kalangan masyarakat. 
Ibnu Al-Atsir mengatakan bahwa makna al-mal pada asalnya bermakna segala sesuatu yang dimiliki seperti emas dan perak. Kemudian dimutlakkan menjadi segala yang diperoleh dan dimiliki dari berbagai benda materi. Pada masyarakat Arab kata almal diidentikkan dengan onta, karena itulah harta benda yang banyak mereka miliki.

Sebagian ulama berbeda pendapat tentang definisi dari harta, Ulama Hanafiyah menganggap bahwa harta adalah :

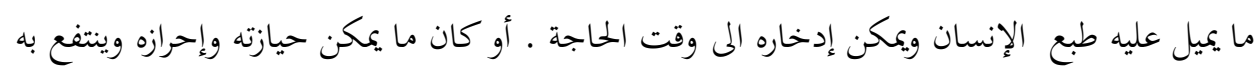

Segala yang diminati manusia dan dapat dihadirkan ketika diperlukan atau segala sesuatu yang dapat dimiliki, disimpan dan dapat dimanfaatkan (Duraisy, 1997). Definisi ini dikemukakan oleh Ibnu Abidin yang bermadzhab Hanafi, sehingga dalam definisi ini tersirat bahwa harta hanya sebatas sesuatu yang berbentuk materi (benda nyata), sementara manfaat menurut mereka bukanlah harta.

Adapun Jumhur Al-Ulama berpendapat bahwa harta adalah :

$$
\text { كل ما له قيمة يلزم متلفها بضمانه }
$$

Segala sesuatu yang mempunyai nilai dan dapat dikenakan ganti rugi bagi orang yang merusak atau melenyapkannya (Zahrah, $t$ t).

Dua pendapat tentang definisi harta tersebut saat ini telah mengalami perubahan, hal ini terlihat dari definisi para cendekiawan muslim kontemporer yang telah memasukan manfaat sebagai bagian dari harta, misalnya definisi yang diberikan oleh Mustafa Ahmad Al-Zarqa' yang menyatakan bahwa harta adalah :

$$
\text { كل عين ذات قيمة مادية بين الناس }
$$

Sesuatu yang mempunyai nilai materi pada kalangan manusia (Haroen, 2000).

Sementara Ulama kontemporer Wahbah Al-Zuhaily mendefinisikan harta dengan:

$$
\text { كل مايقتض ويحوزه الإنسان بالفعل سواء أكان عينا أم منفعة كذهب أو فضة أو حيوان أو نبات أو منافع }
$$

Sesuatu yang dibutuhkan dan diperoleh manusia baik berupa benda yang tampak seperti emas, perak binatang, tumbuh-tumbuhan, maupun (yang tidak tampak) yakni manfaat seperti kendaraan, pakaian, dan tempat tinggal (Zuhaily, 2002).

Beliau menyimpulkan bahwa pendapat yang benar adalah bahwa manfaat adalah bagian dari harta, hal ini karena nilai dari sebuah harta adalah manfaatnya, yang dimaksud dengan manfaat adalah nilai atau hasil dari harta benda yang berbentuk materi, seperti manfaat dari rumah adalah untuk ditinggali, menaiki kendaraan adalah manfaat sedangkan kendaraan itu sendiri adalah bendanya demikian juga manfaat dari baju adalah kegunaanya (Az-Zuhaily, 2002). 
Al-Qamus Al-Muhith menyrbutkan bahwa kata المال al-mal berarti "Segala yang dapat anda dimiliki dari sesuatu (harta benda)". Definisi yang lebih lengkap disebutkan dalam Mu'jam Al-Wasith :

$$
\text { المال : كل ما يملكه الفرد أو تملكه الجماعة من المتاع أو عرض بتحارة أو عقار أو نقود أو حياوان }
$$

Harta adalah segala sesuatu yang dimiliki oleh seseorang atau dimiliki oleh sekelompok orang dari berbagai jenis perhiasan, barang dagangan, harta benda tidak bergerak (rumah dan tanah), uang dan binatang ternak (Unais, 1972).

Pengertian dari harta juga dapat dikembalikan kepada adat wilayah tertentu, hal ini seperti disebutkan oleh Muhammad Syalaby :

$$
\text { مايمكن حيازته واحرزه والإنتفاع به انتفاعا معتادا }
$$

"Sesuatu yang dapat dikuasai, dapat disimpan serta dapat diambil manfaatnya menurut kebiasaan". Pada pengertian ini terkandung di dalamnya faktor sosiologis yaitu adat atau kebiasaan sebagai suatu unsur dalam memberikan pengertian tentang harta, yakni kebiasaan masyarakat dalam memandang suatu materi apakah sebagai harta atau bukan. Kebiasaan atau tradisi adalah sesuatu yang berkembang dalam masyarakat tertentu (Mas'udi, 2002).

Kesimpulannya adalah bahwa harta dalam konsep Islam adalah "Segala sesuatu yang bernilai baik berupa benda materi ataupun manfaatnya". Sehingga segala sesuatu yang di dalamnya terdapat nilai kebendaan (qimah al-madiyah) yang bermanfaat bagi pemiliknya adalah harta. Hak-hak yang disamakan dengan harta juga adalah bagian dari harta karena ketika hak tersebut telah dimanfaatkan maka ia akan menghasilkan materi yang lainnya, hal ini seperti buah-buahan dan susu hewan yang diperah, jika telah terpisah dari asal materinya maka ia telah menjadi materi tersendiri. Namun jika belum menghasilkan maka ia hanya disebut sebagai hak kebendaan saja dan bukan materi/harta (Abdussalam, 1998).

Maka segala sesuatu yang menurut masyarakat memiliki nilai dan berharga maka bisa disebut harta, kepemilikannya sah dan transaksi dengan obyek ini menjadi sah pula. Sehingga jual beli sesuatu tersebut menjadi sah dan efek dari jual beli tersebut pula menjadai sah dan halal.

\section{Teori Jual Beli dalam Islam}

Kata jual-beli mengandung satu pengertian, yang berasal dari bahasa Arab, yaitu

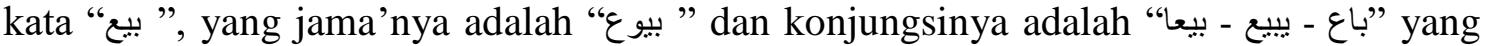
berarti menjual (Munawwir, 2007). M. Ali Hasan (2003) mengemukakan bahwa pengertian jual-beli menurut bahasa, yaitu "menjual, mengganti dan menukar (sesuatu dengan sesuatu yang lain)". Kata الييع dalam bahasa Arab terkadang digunakan untuk pengertian lawannya, yaitu kata الثع (beli). Dengan demikian kata البع berarti kata "jual” dan sekaligus juga berarti kata "beli".

Imam Taqiyuddin Abu Bakar bin Muhammad Al-Hushni (2001) dalam kitabnya Kifayatul Akhyar, juga mendefinisikan jual-beli بيع secara bahasa, sebagai berikut: 


$$
\text { اعطاء شيئ في مقابلة شيئ }
$$

"Memberikan sesuatu karena ada pemberian (imbalan tertentu)". berikut:

Adapun pengertian jual-beli menurut istilah fiqh (Sabiq, 2007) adalah sebagai

Imam an-Nawawi mendefinisikan:

$$
\text { مقابلة مال بمال أو نحوه }
$$

"Saling menukar harta dengan harta lain atau dengan yang sejenisnya (senilai)"

Sayyid Sabiq mendefinisikan:

$$
\text { مبادلة مال علي سبيل التراضي }
$$

"Saling menukar harta dengan harta atas dasar suka sama suka (saling ridlo)".

Ibnu Qudamah mendefinisikan :

$$
\text { مبادلة المال بالمال تمليكا و تملكا }
$$

"Saling menukar harta dengan harta dengan tujuan pemindahan kepemilikan".

Beberapa definisi yang dikemukakan di atas sudah mewakili pendapat ulama yang lainnya, maka dapat disimpulkan bahwa: jual-beli merupakan aktifitas saling menukar harta antara penjual dan pembeli yang dilakukan atas dasar suka sama suka, sehingga keduanya dapat saling memperoleh kebutuhannya secara sah.

Jual-beli juga menciptakan حبل من الناس (hubungan antar sesama manusia) di muka bumi ini dengan alasan agar keduanya saling mengenal satu sama lain, sehingga interaksi sosial dapat terlaksana dengan baik, karena manusia merupakan makhluk sosial.

K. Lubis (2004) menegaskan bahwasannya jual-beli merupakan pertukaran harta antara dua pihak atas dasar saling rela dan memindahkan milik dengan ganti yang dapat dibenarkan, berarti barang tersebut dipertukarkan dengan alat ganti yang dapat dibenarkan. Adapun yang dimaksud dengan alat ganti yang dapat dibenarkan di sini berarti milik atau harta tersebut dipertukarkan dengan alat pembayaran yang sah, dan diakui keberadaannya, seperti uang rupiah dan juga mata uang lainnya.

Adapun syarat dan rukun jual beli secara garis besarnya meliputi Sighah, Aqid, dan Ma'qud 'alaih, dalam suatu perbuatan jual-beli, ketiga rukun ini hendaklah dipenuhi, seandainya salah satunya tidak terpenuhi, maka perbuatan tersebut tidak dapat dikategorikan sebagai perbuatan jual-beli.

\section{Sighah}

Sighah adalah pernyataan kesepakatan dalam berakad dari kedua belah pihak, baik dari penjual atau pembeli. Menurut istilah fiqh shighah disebut juga ijab qabul. Menurut T.M. Hasby ash-Shiddieqy (2001), akad menurut lughah (bahasa) ialah "Ar-Rabthu 
(mengikat) yaitu: mengumpulkan dua tepi tali dan mengikat salah satunya dengan yang lain hingga bersambung, lalu keduanya menjadi satu benda".

Akad menurut istilah "Perikatan antara ijab dengan qabul dengan cara yang dibenarkan syara"e yang menetapkan persetujuan kedua belah pihak". Sedangkan pengertian ijab-qabul yaitu, permulaan penjelasan / pernyataan yang keluar dari salah seorang yang berakad, untuk memperlihatkan kehendaknya dalam mengadakan akad, siapa saja yang memulainya. Adapun qabul yaitu jawaban pihak yang lain sesudah adanya ijab, untuk menyatakan persetujuannya.

Ijab qabul haruslah memenuhi syarat-syarat berikut:

- Keadaan ijab qabul satu sama lainnya harus di satu tempat tanpa ada pemisah yang merusak.

- Ada kesepakatan atau kemufakatan ijab qabul pada barang yang saling ada kerelaan diantara mereka, berupa barang yang dijual dan harga barang. Jika keduanya tidak sepakat maka akad tersebut tidak sah.

- Ungkapan harus menunjukkan masa lalu (madhi), seperti perkataan penjual "aku rela menjual" dan perkataan pembeli "aku telah terima", atau masa sekarang (mudharie) jika yang diinginkan pada waktu itu juga. Jika yang diinginkan masa yang akan datang dan semisalnya, maka hal itu merupakan janji untuk berakad dan janji tidaklah sebagai akad yang sah oleh karena itu tidak sah secara umum (Sabiq, 2007).

- Pada dasarnya ijab qabul itu tidak harus dilakukan dengan lisan, namun akad dalam jual-beli dapat juga dilakukan dengan sesuatu yang menunjukkan pemilikan dan pemahaman dengan apa yang dimaksud. Dengan kata lain, bahwa ijab qabul tersebut tidak harus dengan kata-kata yang jelas, akan tetapi yang dinamakan dalam ijab qabul itu dapat juga dengan maksud dan makna yang dilontarkan antara penjual dan pembeli dengan sindiran atau kata kiasan ataupun isyarat yang dapat dipahami sebagai kebiasaan suatu masyarakat atas kerelaannya (Sabiq, 2007).

\section{Aqid}

Aqid adalah orang yang melakukan akad yaitu penjual dan pembeli. Adapun syarat-syarat aqid adalah:

- Baligh, maksudnya adalah anak yang telah dewasa dan mampu mengelola harta secara cakap agar tidak mudah tertipu.

- Berakal, maksudnya adalah bisa membedakan, supaya tidak mudah terkecoh.

- Tidak Dipaksa, maksudnya adalah orang yang melakukan transaksi harus dilakukan atas dasar suka sama suka. Sebagaimana Rasulullah bersabda:

$$
\text { انما اليع عن تراض }
$$

"Yang dinamakan berjual-beli ialah jika dilakukan dengan sama rela". 
- Tidak mubazir (pemboros) karena harta orang yang mubazir itu ditangan walinya. Firman Allah dalam QS. An-Nisaa: 5,

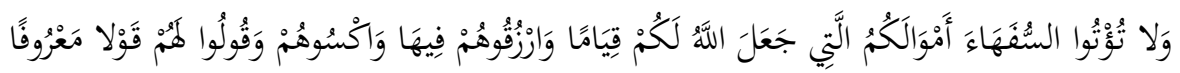

Dan janganlah kamu serahkan kepada orang-orang yang belum sempurna akalnya, harta (mereka yang ada dalam kekuasaanmu) yang dijadikan Allah sebagai pokok kehidupan. Berilah mereka belanja dan pakaian (dari hasil harta itu) dan ucapkanlah kepada mereka kata-kata yang baik.

\section{Ma'qud 'Alaih}

Ma'qud 'alaih adalah barang yang menjadi objek jual beli. Barang yang diperjual belikan haruslah memenuhi syarat-syarat berikut :

- Keadaannya suci, Maksudnya adalah Islam melarang menjualbelikan benda yang najis.

- Memiliki Manfaat, sebagaimana dalam QS. Al-Isra ayat 27.

Barang (sebagai objek jual beli) dapat diserahkan, sebagaimana sebuah riwayat "Dari Abu Hurairah r.a dia berkata : Rasulullah saw melarang jual-beli dengan cara melempar batu dan jual-beli yang mengandung tipu daya". (HR. Muslim No. 1513).

- Barang itu kepunyaan yang menjual, sebagaimana dalam sebuah riwayat "Dari Hakim bin Hizam, ia berkata : Aku pernah bertanya kepada Rasulullah, ya Rasulullah bagaimana tentang seseorang yang datang kepadaku, lalu meminta kepadaku supaya aku menjual sesuatu yang aku tidak memilikinya untuk aku jual dan Beliau menjawab : Janganlah kamu menjual apa yang tidak kamu miliki”. (HR. Abu Daud No. 3503, At-Tirmidzi no. 1232, An-Nasa"i no. 4613, dan Ahmad no. 15311).

- Jelas Barangnya. Barang yang diperjual belikan oleh penjual dan pembeli dapat diketahui dengan jelas dzatnya, bentuknya maupun sifatnya sehingga tidak terjadi kekecewaan diantara kedua belah pihak yang mengadakan jual beli, juga tidak terjadi jual beli gharar, karena hal itu adalah dilarang oleh agama Islam.

- Saksi, Hadits yang diriwayatkan Imam Ahmad, an Nasa ${ }^{e e}$ dan Abu Daud menyebutkan bahwa ada keharusan memakai saksi dalam transaksi jual beli. Hadits tersebut adalah : "Umarah bin Khuzaimah sesungguhnya pamannya telah menceritakannya dan dia termasuk dari beberapa sahabat Nabi. Sesungguhnya Nabi صلى الله عليه وسلم telah membeli seekor kuda dari Arab Badui (penghuni gurun) dan menemuinya untuk membayar seekor kuda. Nabi berjalan cepat sedang sang Badui berjalan lambat. Beberapa orang mencegat orang Badui dan menawar kudanya. Mereka tidak mengetahui bahwa Nabi telah membelinya hingga sebagian dari mereka menambah dalam penawaran apa yang ia beli. Karena itu sang Arab Badui memanggil Nabi dan berkata: Anda jadi membeli kuda ini, jika tidak, aku akan menjualnya kepada orang lain. Kala mendengar ucapan Badui tersebut. Nabi mengatakan : Bukankah kuda ini sudah saya beli, Badui menjawab : Tidak, demi Allah saya tidak 
menjualnya kapada Anda, Nabi berkata aku benar-benar telah membelinya dari kamu maka beberapa orang mencegat Nabi dan orang Badui sedangkan mereka berdua akan pulang, orang Badui mencegat lalu berkata: Ajukanlah saksi yang menyaksikan sesungguhnya aku telah membelinya, Khuzaimah berkata صلى الله عليه sayalah saksinya bahwa engkau telah menjual kepada Rasulullah وسلم, maka Nabi berkata kepada Khuzaimah dengan cara apa engkau menjadi saksi, Khuzaimah menjawab karena membenarkan Anda ya Rasulullah, maka Rasulullah صلى الله عليهوسلم menjadikan kesaksian Khuzaimah sebagai saksi yang dilakukan oleh dua orang". (HR. An-Nasa i no. 4647, Abu Daud no. 3607, dan Ahmad no. 21883).

Merujuk pada rukun dan syarat jual beli tersebut, maka dapat disimpulkan bahwa jual beli dalam Islam menjadi sah apabila terpenuhi rukun dan syaratnya. Apabila tidak terpenuhi maka batal jual beli tersebut. Adapun berkaitan dengan obyek jual beli maka ia memiliki nilai di tengah masyarakat dan bisa dikuasai oleh pihak-pihak yang melakukan jual beli.

\section{Teori 'Urf dalam Islam}

Istilah العرف (al-'urf) secara bahasa berasal dari bahasa Arab, kata ini dibentuk dari huruf ain, ro dan $f a$. Bentuk kata kerja (fi'il)-nya adalah عرف - يعرف ('arafa-ya'rifu) yang berarti mengenal atau mengetahui. Derivatif dari kata ini adalah al-makruf المَعْرُوفن berarti segala sesuatu yang sesuai dengan adat (kepantasan) (Ibnu Mandzur, tt). Sedangkan secara istilah العرف (al-'urf) adalah kebiasaan yang dilakukan oleh kebanyakan masyarakat, baik dalam perkataan maupun perbuatan yang dilakukan secara terus-menerus dan diakui sebagai sesuatu yang baik oleh mereka (Az-Zuhalily, 2002).

Teori 'urf merupakan respon ahli hukum Islam terhadap adat kebiasaan yang berlaku di masyarakat. Inti teori ini adalah bahwa adat kebiasaan yang dilakukan oleh manusia secara berulang-ulang dan dipandang baik oleh mereka bisa diterima oleh Islam sebagai dalil hukum. Sejatinya penyerapan ' $u r f$ sebagai dalil hukum Islam telah dilakukan sejak masa Nabi Muhammad Saw dan para shahabatnya (Al-Madany, 2002). Tradisi ini dilanjutkan oleh para ahli hukum Islam pada masa-masa berikutnya.

Ahli hukum Islam yang menggagas teori ini adalah Malik bin Anas, beliau berpendapat bahwa 'urf masyarakat harus dipertimbangkan dalam memformulasikan suatu ketetapan dalam hukum Islam. Ia menetapkan a'mal penduduk Madinah sebagai sumber hukum ketika tidak ditemukan secara eksplisit dalil dalam al-Quran maupun alHadits (Abu Sinnah, 1947). Ia juga melakukan takhsis terhadap ayat al-Quran dengan 'urf Arab pada permasalahan hak menyusui bagi seorang ibu.

Menurutnya, walaupun ayat ini memerintahkan para ibu untuk menyusui anaknya hingga dua tahun, namun dalam praktiknya ibu-ibu di Arab telah terbiasa dengan menyusukan anak-anaknya kepada perempuan-perempuan dari wilayah pedalaman dengan harapan anak-anaknya tersebut mendapatkan pendidikan dan lingkungan pertumbuhan yang baik.

Al-Syafi'i menggunakan 'urf sebagai dalil dalam menetapkan suatu hukum Islam, terlihat dari perubahan hukum ketika ia berpindah dari Baghdad ke Mesir dengan 
pertimbangan 'urf penduduk Mesir (Mubarak, 2002). Fuqaha Syafiiyyah yang membahas masalah 'urf adalah al-Suyuti, ia menyatakan:

$$
\text { أن اعتبارالعادة والعرف رُجِعَ إليه في الفقه في مسائل لاتُعَدُّثرة }
$$

Bahwa adat dan 'urf merupakan sumber hukum yang bisa memecahkan dalam berbagai persoalan (As-Suyuti, $t$ t).

Abu Hanifah telah banyak menggunakan istihsan yang salah satunya menjadikan adat kebiasaan sebagai bahan pertimbangan. Metode ini diteruskan oleh murid-muridnya yaitu Abu Yusuf, Sarakhsi dan Syaibani. Abu Yusuf berpendapat bahwa 'urf menjadi bahan pertimbangan utama dalam sistem hukum Hanafiyah, ketika nash yang jelas tidak ditemukan (Hummam, 1937). Menurut Sarakhsi, Abu Hanifah akan menolak qiyas untuk lebih memilih 'urf (Al-Sarakhsi, 1912).. Muhammad Syaibani merumuskan beberapa syarat yang memungkinkan 'urf diterima oleh hukum Islam.

Ahmad bin Hambal dan pengikutnya menggunakan 'urf sebagai sumber hukum Islam. Ibnu Qudamah berpendapat bahwa 'urf dianggap sebagai sumber hukum Islam dan ia menguatkan aturan-aturan fiqhnya dengan merujuk kepada adat (Ibnu Qudamah, 1947). Al-Tufi menjadikan 'urf sebagai salah satu dari sembilan belas sumber hukum dalam Islam. Ahli hukum Islam dari mazhab Hambali berikutnya yang membahas tentang 'urf adalah Ibnu Taimiyah dan muridnya Ibnu al-Qayyim al-Jauziyah. Ia mencatat dalam kitabnya I lamul Muwaqqi'in:

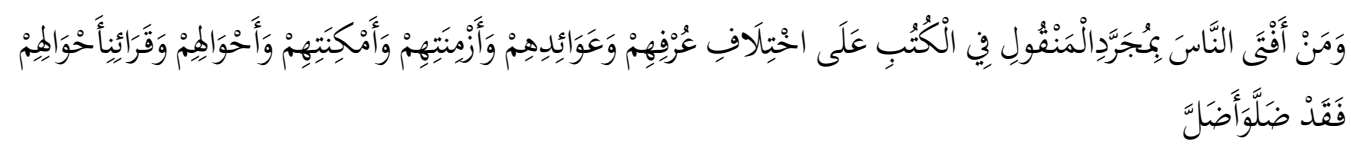

Sesungguhnya orang yang berfatwa hanya berdasarkan dalil naqli dan bertentangan dengan tradisi, urf, situasi, dan kondisi masyarakat maka berarti dia telah berlaku sesat dan menyesatkan

Selain ahli hukum Islam dari empat mazhab klasik, ahli hukum Islam kontemporer juga menyepakati bahwa 'urf menjadi bahan pertimbangan dalam menetapkan hukum Islam. Sehingga bisa dikatakan bahwa jumhur fuqaha salaf dan khalaf telah sepakat mengenai kedudukan 'urf sebagai dalil hukum Islam.

Merujuk pada teori 'Urf maka kesepakatan pada masyarakat yang dianggap baik bisa dijadikan dalil dalam hukum Islam, khususnya dalam bidang muamalah maka umat Islam diberikan kebebasan untuk melaksanakannya.

\section{Hasil dan Pembahasan}

\section{Virtual Property dalam Game Online}

Richard A. Bartle mengungkapkan bahwa ada tiga kategori besar dan tiga kategori kecil dari virtual property di dalam permainan game online, yaitu :

Kategori besar : Benda-benda (senjata, pakaian pelindung, perhiasan, tameng, dan benda-benda sejenis lainnya yang digunakan untuk bertarung melawan musuh).Karakter 
(Karakter di sini adalah karakter yang digunakan oleh seseorang dalam memainkan permainan online tersebut). Mata uang (gold, platinum, pyreals).

Kategori kecil : Virtual estate (meliputi rumah, toko, dan berbagai bangunan lainnya di dalam permainan online). Akun (akun yang dibuat oleh pemain suatu permainan online untuk dapat masuk ke dalam permainan online tersebut). Hal-hal lainnya (meliputi perizinan, keanggotaan, peta, dan lain sebagainya).

Virtual property sebagaimana yang telah disebutkan di atas, pada kenyataannya memiliki nilai bukan hanya di dunia virtual di dalam permainan online tersebut berlangsung, namun juga di dunia nyata. Virtual property tersebut diperjualbelikan di dunia nyata dengan menggunakan mata uang asli di dunia nyata.

Maka ada dua hal yang menjadi inti permasalahannya apabila dilihat dalam perspektif hukum ekonomi syariah, yaitu; status keberadaan dari Virtual Property, kepemilikan atasnya dan jual beli dengan obyek tersebut.

\section{Eksistensi Virtual Property dalam Perspektif Hukum Ekonomi Syariah}

Virtual property yang diperjualbelikan di dalam game online memiliki arti bahwa hal tersebut memiliki nilai tersendiri layaknya sebuah harta. Mengutip tulisan yang dibuat oleh Petteri Günther di dalam artikelnya yang berjudul Virtual Goods and Regulatory Insights from the European Perspective, dikatakan bahwa permasalahan terhadap pengaturan mengenai virtual property itu sendiri belum terpecahkan baik di Eropa, Amerika Serikat, maupun di berbagai negara lainnya.

Permasalahan yang dimaksud adalah Real Money Transfer guna membeli virtual property di dalam suatu game online, yang dilakukan oleh banyak player game online di berbagai belahan dunia. Jika, memperhatikan permasalahan tersebut, maka akan didapatkan permasalahan mengenai bagaimanakah pandangan Islam terhadap virtual property tersebut. Di sini, virtual property tersebut diperlakukan sebagai barang yang nyata.

Padahal, jika diperhatikan dengan seksama virtual property di sini hanyalah bersifat maya saja, tidak dapat disentuh, dan hanya dapat dilihat saja. Virtual property itu juga terikat dengan game online tempat virtual property tersebut berada, artinya, virtual property tersebut hanya memiliki nilai dan bahkan hanya dapat diakses di dalam game online yang bersangkutan. Meskipun virtual property itu bersifat maya atau tidak nyata, namun ternyata di dalam prakteknya virtual property tersebut dapat diperdagangkan, bahkan memiliki nilai yang dapat dinilai dengan mata uang yang sesungguhnya.

Persyaratan sesuatu disebut sebagai harta dan sah dalam kepemilikannya adalah bekaitan dengan sesuatu tersebut apakah memiliki nilai di tengah manusia atau tidak. Virtual Property walaupun tidak berwujud sebagai benda namun ia memiliki nilai dan berharga bagi komunitas gamer sehingga kesepakatan mereka tentang hal ini bisa dijadikan dalil. Sehingga Virtual Property dalam perspektif hukum ekonomi syariah bisa diterima sebagai harta, sehingga kepemilikan akannya menjadi sah secara syar'i. 


\section{Jual Beli Virtual Property dalam Hukum Ekonomi Syariah}

Kini game online dapat dijadikan cara untuk mencari uang, yaitu dengan cara menjual virtual property yang ada dalam game online tersebut. Awalnya memang hanya ada di luar negeri, tapi sejak adanya game online Nexia yang merupakan game online pertama di Indonesia, Para gamer memanfaatkannya untuk mencari keuntungan pribadi dari jual-beli karakter atau perlengkapan tempur tokoh fantasi yang dimainkannya dalam game tersebut.

Transaksi bisa dilakukan kedua gamer melalui karakter yang mereka pertemukan di arena hunting (arena Game). Di sana mereka dapat memanfaatkan fasilitas chatting untuk bertransaksi. Melalui chatting, mereka memperbincangkan harga hingga lokasi tempat mereka dapat bertemu atau nomor rekening tabungan sebagai tujuan transfer uang. Jadi, dapat disimpulkan bahwa sistem jual beli benda maya dalam game online ada dua cara yaitu melalui dunia nyata secara langsung dan melalui chatting yang terdapat pada fasililitas game tersebut.

Di dalam transaksi jual beli, tidak terlepas dari beberapa syarat dan rukun yang perlu sebagai peraturan dalam bertransaksi jual beli. Sehingga transaksi tersebut menjadi sah sesuai dengan yang ditentukan dalam perjanjian. Sedangkan transaksi jual beli dalam Islam telah ditentukan oleh para kalangan ulama ${ }^{\text {ee }}$ dengan mengacu pada nash Al-Qurean dan sunnah Rasulullah SAW.

Syarat dan rukun jual beli merupakan pokok ulama' yang perlu diketahui dan diterapkan, agar para pihak penjual dan pembeli tidak terjerumus dalam transaksi yang dilarang oleh syariat, sehingga dalam transaksi jual beli terjalin suatu transaksi yang memenuhi syariatnya.

Terkait persoalan syarat dan rukun jual beli, maka dalam jual beli virtual property dalam game online terdapat syarat dan rukun yang harus ditepati. Sedangkan yang membedakan dalam jual beli virtual property dalam game online adalah mengenai virtual property yang merupakan benda tak berwujud (intangible) serta proses transaksi yang belum jelas ketentuannya.

Hukum Ekonomi Syariah tentang Jual Beli Virtual Property dalam Game Online Jual beli mempunyai rukun dan syarat yang harus dipenuhi, sehingga jual beli itu dapat dikatakan sah oleh syara'. Ada perbedaan pendapat mengenai rukun jual beli, menurut ulama Hanafiyah rukun jual beli hanya satu, yaitu ijab (ungkapan membeli dari pembeli) dan qabul (ungkapan menjual dan menjual).

Mereka berpendapat seperti ini, karena menurut mereka rukun dalam jual beli itu hanyalah kerelaan antara penjual dan pembeli, akan tetapi karena unsur kerelaan itu merupakan unsur hati yang sulit untuk diindera sehingga tidak kelihatan, maka diperlukan indikator yang menunjukkan kerelaan tersebut dari kedua belah pihak dapat dalam bentuk perkataan, yaitu ijab dan qabul atau dalam bentuk perbuatan, yaitu saling memberi (penyerahan barang dan penerimaan uang).

Sedangkan jumhur ulama' berpendapat bahwa rukun jual beli ada empat, yaitu:

- Al-muta'aqidain (penjual dan pembeli) 
- Sigat (lafal ijab dan qabul)

- Ma'qud 'alaih (barang yang dibeli)

- Nilai tukar pengganti barang

Menurut ulama Hanafiyah, orang yang berakad, barang yang dibeli, dan nilai tukar barang termasuk ke dalam syarat-syarat jual beli, bukan rukun jual beli. berikut:

Syarat barang yang diperjualbelikan menurut pendapat para jumhur adalah sebagai

- Suci (halal dan baik)

- Memberi manfaat menurut syara'

- Milik orang yang melakukan akad

- Mampu diserahkan oleh pelaku akad.

- Mengetahui status barang (kualitas, kuantitas, jenis dan lain-lain.).

- Barang tersebut dapat diterima oleh pihak yang melakukan akad.

- Berdasarkan keenam syarat ma'qud alaih menurut jumhur ulama serta pandangan penulis maka, penulis berkesimpulan melalui metode 'urf yang menjadi metode istinbath hukum penulis bahwa hukum melakukan jual beli virtual property dalam Islam adalah dibolehkan.

Dengan melihat syarat-syarat ma'qud alaih maka dapat dipenuhi oleh kriteria virtual property dalam game online, sehingga jual belinya sah dan halal. Hal ini merujuk pada keberadaan dari virtual property yang juga bisa dianggap sebagai harta yang kepemilikannya dilindungi syara'

\section{KESIMPULAN}

Berdasarkan pembahasan mengenai virtual property dalam perspektif Hukum Ekonomi Syariah, maka dapat disimpulkan bahwa Virtual Property dalam perspektif hukum ekonomi Islam diangap sebagai harta yang memiliki nilai khususnya pada komunitas tersebut. Sehingga kepemilikan akan harta ini menjadi sah dan halal. Virtual Property sebagai harta didasarkan pada teori urf dalam Islam di mana harta adalah segala sesuatu yang diyakini dan dianggap memiliki nilai di tengah masyarakat. Jual beli virtual property dalam Islam sah secara syara' dikarenakan telah terpenuhi rukun dan syarat jual beli. Adapun yang berpendapat bahwa ia tidak bisa dijadikan obyek akad maka pendapat ini dibantah dengan rukun dan syarat jual beli yang sudah sah, serta obyek jual beli tersebut halal dan tidak najis. Dengan demikian maka, virtual property dalam game online menjadi bagian dari harta dalam Islam dalam bentuk manfaat.

\section{REFERENCE}

Abady, Al-Fairuz. Al-Qamus Al-Muhith. Libanon : Muasasah Ar-Risalah, 1998. 
Misno

Abu Abdillah Muhammad bin Ahmad Ibnu Qudamah, al-Mughni, Kairo: Daar al-Manar, 1947.

Adil Muhammad Muhammad Duraisyi, Nidzam Al-mal Fi Al-Islam, Dar Al-Kutub, tahun 1997.

Ahmad Fahmi Abu Sinnah, Al-'Urf Wal 'Adah fi Ra'yil Fuqaha, Mesir: Mathba'ah AlAzhar, tahun 1947.

Al-Hushni, Taqiyyuddin Abu Bakar Muhammad. Kifayatul Akhyar. Beirut: Dar al-Kutub al'Ilmiyah, 2001.

Al-Sarakhsi, Al-Mabsuth, Kairo: Maktabah al-Sa'adah, 1912, jilid 12.

Al-Zuhaily, Wahbah. Al-Fiqh Al-Islam Wa Adilatuhu Juz IV. Damaskus : Darul Al-Fikr, $2002 \mathrm{M} / 1422 \mathrm{H}$.

Ash-Shiddieqy, T.M. Hasbi. Pengantar Fiqh Muamalah. Semarang: Pustaka Rizki Putra, 2001.

Hasan, Muhammad Ali. Berbagai Macam Transaksi dalam Islam Fiqh Muamalat. Jakarta: PT. Raja Grafindo Persada, 2003.

Ibnu Hummam, Syarh Fathu al-Qadir, Kairo: Matba'at Musthafa Muhammad, 1937, jilid 5.

Izzudin bin Abdissalam, Qawaid Al-Ahkam fi Mashalih Al-Anam Juz II, Beirut : Muasasah Ar-royyan, cet. II tahun 1998 M/ 1419 H.

Jaih Mubarak, Modifikasi Hukum Islam: Studi tentang Qawl Qadim dan Qawl Jadid, Jakarta : Rajagrafindo Persada, 2002.

Jalaluddin al-Suyuti, al-Asybah wa Nadzair, Beirut : Daar Al-Kutub al- Araby, tt.

Louis Ma'luf, al-Munjid Fi al-Lughah wa al-A'lam, Beirut : Dâr Masyriq, 1982.

M. Ali Hasan, 2004. Berbagai Macam transaksi Dalam Islam, Jakarta: Rajagrafindo Persada.

Mas'udi, Ghufron A. Fiqh Muamalah Kontekstual. Jakarta : PT RajaGrafindo Persada, 2002.

Muhammad Abu Zahrah, Al-Milkiyah Wa Nadzariyah Al-'Aqd, Dar Al-Fikr Al-Araby

Muhammad Muhammad al-Madany, Nadzaraat fi Fiqh al-Faruq Umar ibn al-Khattab, Kairo: Wizarah al-Auqaf, 2002.

Munawwir, A.W. Kamus Al-Munawwir Indonesia Dan Arab. Surabaya: Pustaka Progressif, 2007.

Nasroen Haroen, Fiqh Muamalah, Gaya Media Pratama : Jakarta, 2000.

Prawiro, Abdurrahman Misno Bambang, Hak Cipta Karya Tulis dalam Hukum Islam, Yogyakarta: Deepublish, 2016.

Rachmat Syafe'i, Fiqih Muamalah, Pustaka Setia : Bandung, 2004. 
Virtual Property Pada Game Online Dalam Perspektif Hukum Ekonomi Syariah

Sabiq, Sayyid. Fiqih Sunnah. Penerj. Nor Hasanuddin. Vol. Jilid 3. Jakarta: Pena Pundi Aksara, 2007.

Unais, Ibrahim, et.all. Mu'jam Al-Wasith. Kairo, 1972. 